\title{
MA-パルス通電焼結プロセスによる複合磁性材料の作製
}

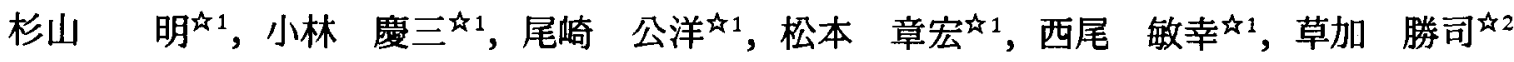 \\ 41 名古屋工業技術研究所, ₹ 462-8510 名古屋市北区平手町 1-1. \\ 舐大同工業大学, 干 457-8531 名古屋市南区大同町 2-21.
}

\section{Preparation of Duplex Phase Magnetic Materials by MA-Pulsed Current Sintering process}

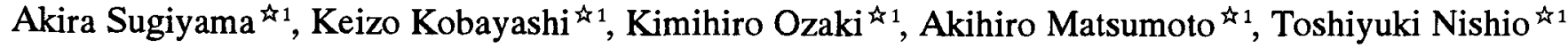 \\ and Katsushi Kusaka 2 \\ 41 National Industrial Research Institute of Nagoya, AIST, MITI, 1-1 Hirate-cho Kita-ku, Nagoya 462-8510. \\ ${ }^{2}$ Daido Institute of Technology, 2-21 Daido-cho Minami-ku, Nagoya 457-8531.
}

Received March 8, 2000

\begin{abstract}
SYNOPSIS
Preparation of duplex phase magnetic materials, which consisted of giant magnetostrictive ( $\left.\mathrm{Tb}_{0.5} \mathrm{Dy}_{0.5}\right) \mathrm{Fe}_{1.8}$ and zero magnetostrictive $\mathrm{Fe}-6.5$ mass\% $\% \mathrm{Si}$ alloys was investigated. The giant magnetstrictive $\left(\mathrm{Tb}_{0.5} \mathrm{Dy}_{0.5}\right) \mathrm{Fe}_{1.8}$ powders were synthesized by the mechanical alloying (MA) method. The zero magnetostrictive Fe-6.5mass\%Si alloy powders was produced by the water atomization method. The MA was performed in a planetary ball mill. These powders were consolidated at $1273 \mathrm{~K}$. Each powder was filled and sintered in stratified formation in order to make the duplex phase magnetic material. However, the minimum thickness of sintered sample without breaking was $2 \mathrm{~mm}$. To get thinner sintered duplex phases magnetic material, at first only the zero magnetostrictive $\mathrm{Fe}-6.5$ mass \% Si alloy were sintered. Then the sintered compact was planed the surface to thickness of $0.2 \mathrm{~mm}$. This thin plate was put on the punch in the die. The giant magnetstrictive $\left(\mathrm{Tb}_{0.5} \mathrm{D} \mathrm{y}_{0.5}\right) \mathrm{Fe}_{1.8}$ powders were filled up on this plate in the die to sinter at $1273 \mathrm{~K}$. The thickness of this sintered sample was $0.6 \mathrm{~mm}$. The diffusion layer, which is expected as the buffer of the stress produced by bending-was not observed at the interface.
\end{abstract}

KEYWORDS

giant magnetostriction, zero magnetostriction, duplex phase, mechanical alloying

\section{1 緒 言}

最も大きな磁歪を示す金属間化合物相として知られている ラーベス相化合物， $\mathrm{TbFe}_{2}$ は A.E.Clark ら ${ }^{1)}$ にっつて報告され た.しかし，超磁歪材料には大きな磁歪を得るために大きな 磁界が必要であるという問題点があった。磁歪材料の実用化 を考慮すると，大きな磁界で大きな磁歪を得るよりは，むし ろ小さな磁界で，変化率の大きな磁歪を得る必要がある．さ らに，機械的性質においても，ラーベス相化合物は金属間化 合物特有の脆性を示す.そのため, 実用材料としての繰り返 し使用などを考虑すると，脆性を改善する必要がある．また， 磁歪材料は単層では基本的に伸縮運動であり，アクチュエー 夕等の実用化を考慮する場合, 反り等を生じさせることが必 要である。

磁歪の改善に関しては， $\mathrm{Tb}_{0.3} \mathrm{Dy}_{0.7} \mathrm{Fe}_{2}$ 組成の薄膜に関して熱 処理の効果についての研究》や, 急冷効果についての研究引, 粉 末治金的手法による研究 ${ }^{4,5}$ が行われている.また，希土類元
素と遷移金属元素間の相互作用に関する詳細な報告のもなさ れている.反りを利用したアクチュエータに関する研究では， 高分子材料に磁歪材料の膜を成膜した応用研究》がなされて いる.さらに磁歪の測定方法そのものに関しても研究名がな されている.

著者らは, $\mathrm{Tb}, \mathrm{Dy}, \mathrm{Fe}$ の素粉末を, メカニカルアロインク (以下 MA) 法により湿合し, Tb-Dy-Fe合金の合成に成功した. さらに, 合成された粉末を, パルス通電焼結法 (以下 PCS) 法 により固化することに成功した。 その中でMA条件，成形条 件や得られた成形体の磁気特性について詳細に調查した ${ }^{9,10)}$. 本研究では，MA-PCS プロセスによって作製された超磁歪特 性を示すTb-Dy-Fe合金の脆性改善および反りの発生を目的と して磁歪を示さない金属材料との複合化を試みた。

\section{2 実験方法}

$\mathrm{Tb}(99.9 \mathrm{mass} \% \mathrm{~Tb}$ ，粒径約 0.8mm) 粉, Dy (99.9mass\%Dy，粒 
径約 $0.8 \mathrm{~mm})$ 粉, $\mathrm{Fe}(99.85 \mathrm{mass} \% \mathrm{Fe}$ ，粒径約 $100 \mu \mathrm{m})$ 粉の素粉 末を出発原料として, $\left(\mathrm{Tb}_{0.5} \mathrm{Dy}_{0.5}\right) \mathrm{Fe}_{1,8}$ 組成の粉末をメカニカル アロイング(以下MA)法を用いて合成した. なお, 組成はこれ までの結果”をもとに決定した. MAは遊星型ボールミル(伊 藤製作所製：LA-PO.4)を用いた. 酸素, 窒素の混入を防ぐた め, 容器内を真空に排気した後, $20 \mathrm{kPa} の \mathrm{Ar}$ 霝囲気で置換し た.ミリングは360ks間行った. MAで使用したボールおよび 容器は $\mathrm{Cr}$ 鋼 (11mass\% $\mathrm{Cr}$ ) 製とした. 試料重量はボールの重量 の1/20とした.ミリングに際しては助剮などは使わなかった.

磁歪特性を示さないぜ口磁歪材料として, Fe-6.5mass\% \% Si合 金を使用した. Fe-6.5mass\%Si合金粉末は水アトアイズ法によ り作製し，粒径 $35 \mu \mathrm{m}$ 以下に分級して使用した。

得られた粉末はパルス通電焼結装置(Pulsed Current Sintering device) (住友石炭鉱業製: SPS-510L)(以下 PCS)で成形を行った. 成形では, $5 \times 30 \mathrm{~mm}$ のカーボン製ダイ, カーボン製バンチ，ま たは $5 \times 30 \mathrm{~mm}$ の超硬合金製ダイ , パンチによって最高 $250 \mathrm{MPa}$ の圧力を加えた. 焼結は $10 \mathrm{~Pa}$ の減圧需囲気中で行い, 昇温速 度 $50 \mathrm{~K} / \mathrm{min}$ で，最高 $1273 \mathrm{~K}$ まで加熱し 300 秒間保持した。な お, カーボン製のダイは強度の関係から割型とし，一番外側 のC/Cコンボジットの円筒が円筒内部を 4 つのパーツを押さ え込み, $5 \times 30 \mathrm{~mm}$ の長方形の穴を空ける構造とした.一方, 超 硬合金製のダイは一体成形とした。

MA粉, 成形体はX線回折法により構成相の同定を行った. また，SEMによる組織観察，EDXによる成分分析を行った。

\section{3 実験結果および考察}

\section{1 超磁歪材料およびゼ口磁歪材料の特性}

著者らはこれまでに, $\left(\mathrm{Tb}_{\mathbf{x}} \mathrm{Dy}_{1-\mathrm{x}}\right) \mathrm{Fe}_{1.8}$ 組成の粉末を MA法を 用いて合成し，PCS 法により成形を試みてきた》。その中で，

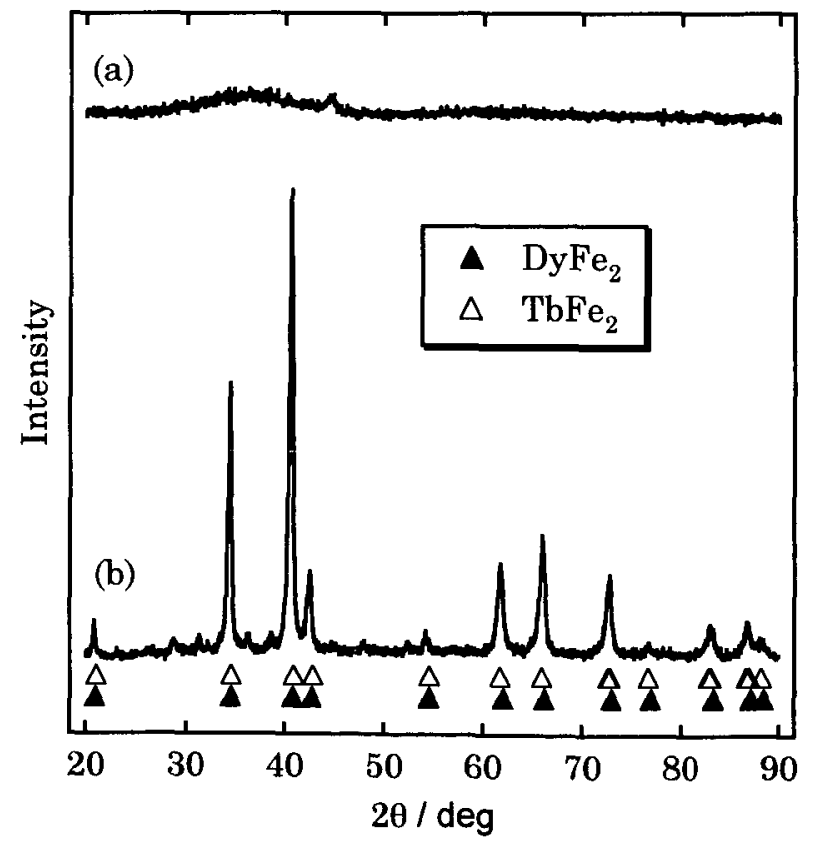

Fig.1 XRD patterns of $\left(\mathrm{Tb}_{0.5} \mathrm{Dy}_{0.5}\right) \mathrm{Fe}_{1.8}$ alloy. (a) mechanically alloyed powders milled for $360 \mathrm{ks}$ and (b) sintered at $1273 \mathrm{~K}$.
ミリング時間が $360 \mathrm{ks}$ になると，得られた粉末の X 線回折結 果がアモルファスに近いフロードなピークとなること, $\mathrm{x}=0.5$ すなわち $\left(\mathrm{Tb}_{0.5} \mathrm{Dy}_{0.5}\right) \mathrm{Fe}_{18}$ 組成の粉末は $41 \mathrm{MPa} ， 1273 \mathrm{~K}$ で 300 秒 間保持して固化した場合にラーベス相 $\left(\mathrm{TbFe}_{2}, \mathrm{DyFe}_{2}\right)$ 以外のX 線回折ピークが最も小さくなることなどを明らかにした (Fig.1). そこで, 本研究では主として360ks 間ミリンクを行っ た $\left(\mathrm{Tb}_{0.5} \mathrm{Dy}_{0.5}\right) \mathrm{Fe}_{1.8}$ 組成の粉末を用いた.

Fig.2に水アトマイズ法で作製した(a) Fe-6.5mass\%Si合金粉 末, および(b)その成形体の X線回折結果を示す.なお，成形 はPCS 法により，41MPa，1273Kの条件で 300 秒間保持して 行った。状態図からも明らかなように粉末，成形体ともに Si が $\mathrm{Fe}$ 中に固溶しており, $\mathrm{Fe}$ のビークのみが観察された.また， 粉末に比へて成形体の X線回折ピークはより鋭くなり, PCS 法による温度変化によって結晶粒径が大きくなったものと思 われる。

次に，360ks ミリングによって作製した $\left(\mathrm{Tb}_{0.5} \mathrm{Dy}_{0.5}\right) \mathrm{Fe}_{1.8}$ 粉末 ならびに Fe- $6.5 \mathrm{mas} \% \mathrm{Si}$ 粉末を黒鉛型を用いて， $5^{\mathrm{m}} \times 30^{\prime} \times 2^{\prime} \mathrm{mm}$ の大きさに成形した. 成形はPCS 法により $1273 \mathrm{~K} て ゙ 5$ 分間保 持して行った. なお，単層で試料を作製する場合，割れるこ となく安定して成形できる厚さは $0.5 \mathrm{~mm}$ であった。これは, 成型時に使用するのが黒鉛の割型であるため寸法精度が低く， 型に組んだとき若干隙間が生じること，またパンチと粉末と 間に反応を抑えるための厚さが約 $0.2 \mathrm{~mm} て ゙ ，$ 厳密に均一では ないカーボンシートを使用していることが原因であると思わ れる.すなわち， $0.5 \mathrm{~mm}$ 以下の厚さに成形する場合，カーボ ンシート等の影響で試料部の厚さが均一でないため高温時の 粉末の流動が十分に起こらず，㜊密化過程において密度が低 い部分が生じ，割れが生じたものと思われる，得られた成形 体はさらに磁場中での伸びを測定し，磁界に対する伸びの依

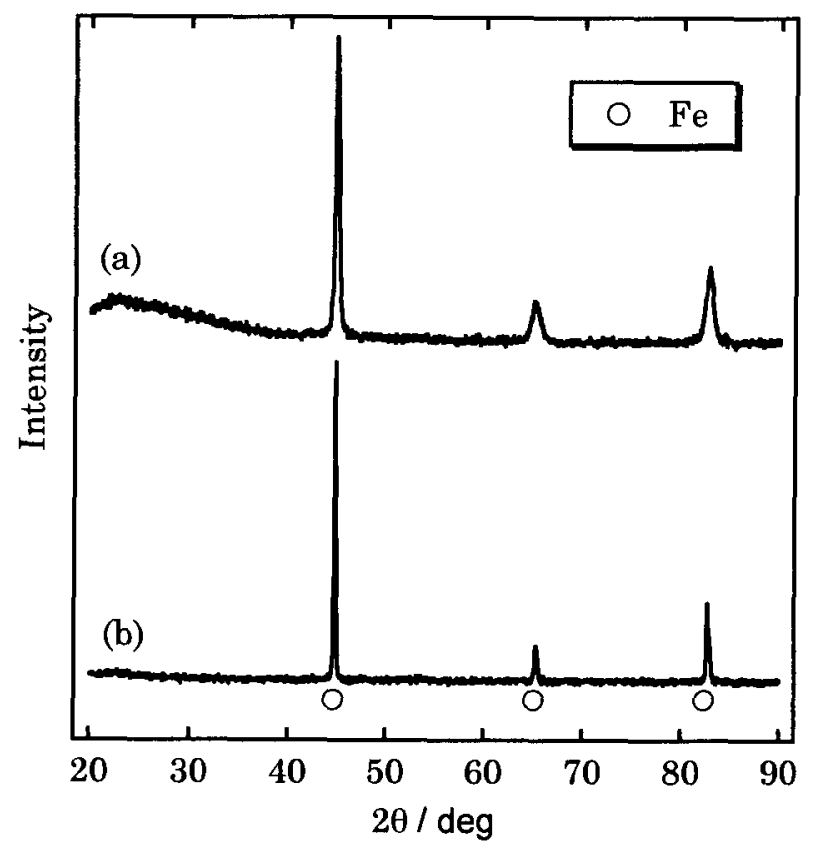

Fig.2 XRD patterns of Fe-6.5mass\%Si alloy. (a) gas atomized powders and (b) sintered at $1273 \mathrm{~K}$. 
存性を Fig.3にまとめた．超磁歪材料である $\left(\mathrm{Tb}_{0.5} \mathrm{Dy}_{0.5}\right) \mathrm{Fe}_{1.8}$ 合 金は $110 \mathrm{kA} / \mathrm{m}$ の磁場中で約 $250 \times 10^{-6}$ の磁歪を示したのに対 し, $\mathrm{Fe}-6.5 \mathrm{mass} \% \mathrm{Si}$ は全く磁歪を示さないことがわかった. 従って,これらの材料を層状に積層することによって, 一方 向に反りを生じる材料が得られる可能性がある.

3.2 複合磁性材料の作製

超磁歪材料とゼロ磁歪材料の複合化を行った. 超磁歪材料 の複合化は, Fig.4に模式的に示すように, $\left(\mathrm{Tb}_{0.5} \mathrm{Dy}_{0.5}\right) \mathrm{Fe}_{1.8}$ 組成 の合金と $\mathrm{Fe}-6.5 \mathrm{mass} \% \mathrm{~S}$ 合金を, PCS成型時の型内に層状に充

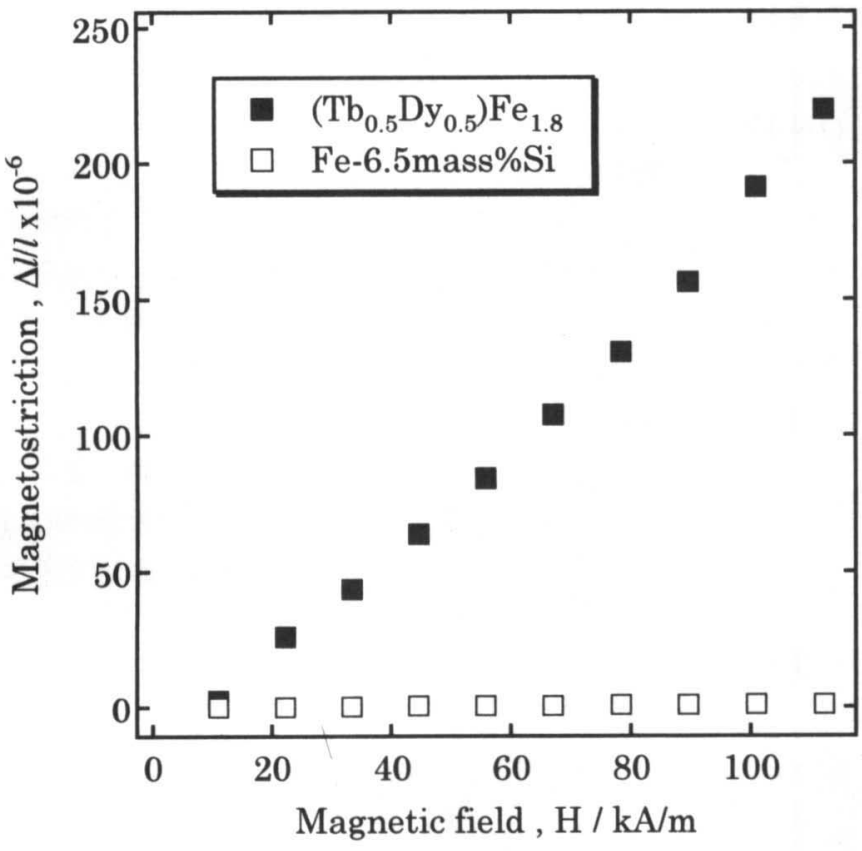

Fig.3 Magnetostriction of $\left(\mathrm{Tb}_{0.5} \mathrm{Dy}_{0.5}\right) \mathrm{Fe}_{1.8}$ and $\mathrm{Fe}-6.5$ mass $\% \mathrm{Si}$ sintered at $1073 \mathrm{~K}$.

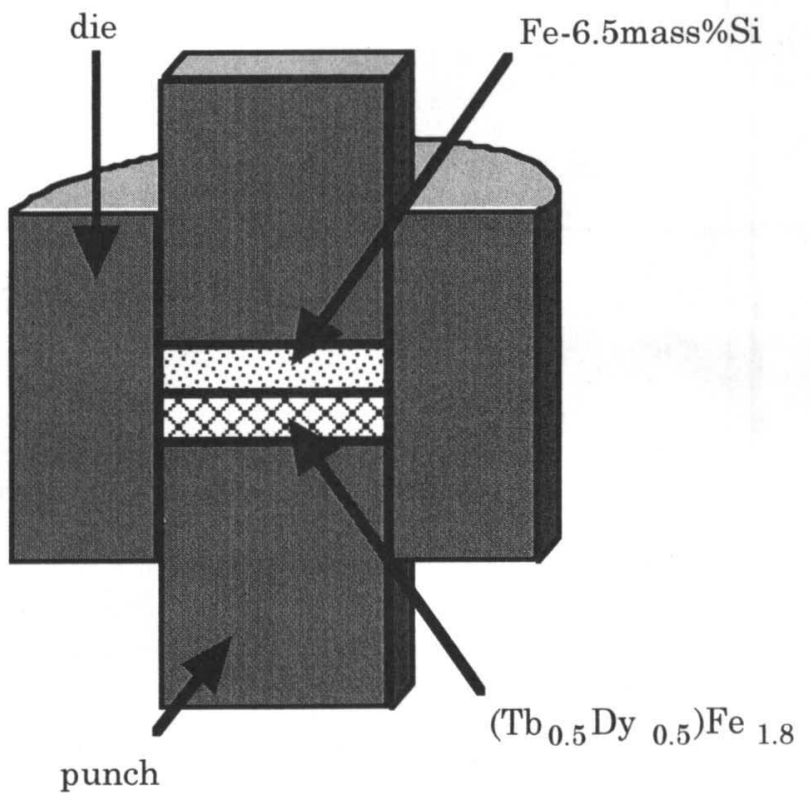

Fig.4 Schematic of filling conditions of $\left(\mathrm{Tb}_{0.5} \mathrm{Dy}_{0.5}\right) \mathrm{Fe}_{1.8}$ and $\mathrm{Fe}-$ 6.5 mass $\%$ Si powders in the die.
填して焼結することによって行った，ところで，複合型磁歪 材料が大きな反りを生じるためには，それぞれの層ができる だけ薄く, 厚みが均一である必要がある. また, 界面付近に は大きな応力が発生することが予想されるため, 組成的に傾 斜した拡散層を形成して応力を緩和するような構造とする必 要があると思われる. そこで，まず，粉末の状態でそれそれれ の合金を積層化し， 1 回の焼結で 2 層同時に固化成形を試み た. 粉末の状態で積層化することにより，粉末充填段階で界 面付近に乱れが生じ, 組成傾斜的な拡散層の形成が容易にな るものと考えられた. PCS 法により 41MPa，1273Kで 300 秒 間保持して得られた成形体のSEM 像 (界面付近)を Fig.5に示 す. EDX 分析の結果, より暗い領域が $\mathrm{Fe}-\mathrm{Si}$ 層であり, 明るい 領域が TbDy-Fe 層であった. それぞれの粉末を単層で焼結し た場合に比べて,非常に孔が多く密度が低いことがわかった。 これは，機械的性質が異なる粉末を層状に積層したことで圧 力が均等に伝わらなかったためであると考えられる.さらに， PCS 法では焼結中に試料を一軸で加圧しているため界面付近 ではより圧力が均等に伝わらなかった可能性がある. 界面は それぞれの粉末が入り組んでいるが比較的整合性を保ってい た.さらに，界面を横切るように EDXにて線分析した結果， 本研究の分解能では組成傾斜的な拡散層は得られなかった. この手法による成形体は厚さが約 $2 \mathrm{~mm}$ となったが各層の厚さ が不均一であり，焼結が不十分で粉末の状態で残存している 部分が見られた. そのため, さらに薄い試料を作製する場合 には試料の中程で割れてしまい, 完全な成形体は得られな かった. そこで,ささらに薄く均一な層を作製するために, 超 硬合金製の型をもちいて一度高圧で仮焼結する手法を試みた。 $\mathrm{Fe}-6.5 \mathrm{mass} \% \mathrm{Si}$ の粉末のみを超硬合金製の型に充填した後, 一 度室温で加圧してから $\left(\mathrm{Tb}_{0.5} \mathrm{Dy}_{0.5}\right) \mathrm{Fe}_{1.8}$ の粉末を充填し，2層状 態とした後に $130 \mathrm{MPa}, 573 \mathrm{~K}$ の条件で焼結を行い，複合型磁 歪材料の仮焼結体を作製した.この条件で得られた成形体は 前出と同様に $5^{\mathrm{w}} \times 30^{1} \times 2^{\mathrm{t}} \mathrm{mm}$ であった．また，超硬合金製の型 は寸法精度が高く，パンチ，ダイともに平行，垂直面が正確 に加エされているため, 得られた成形体の各層の厚みもほぼ

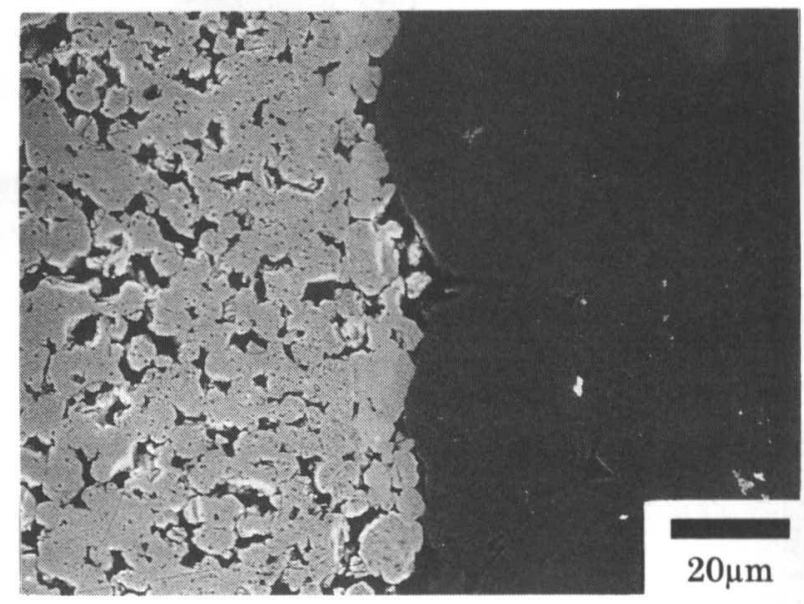

Fig.5 SEM image of sintered $\left(\mathrm{Tb}_{0.5} \mathrm{Dy}_{0.5}\right) \mathrm{Fe}_{1.8} / \mathrm{Fe}-6.5 \mathrm{mass} \% \mathrm{Si}$ interface. 
一定となった．次に，成形体の密度を高めるため，仮焼結体 を黒鉛製の型に装填し, $41 \mathrm{MPa}, 1273 \mathrm{~K}$ の条件で本焼結を行っ た. 得られた成形体の厚さは約 $1.5 \mathrm{~mm}$ であった.このように して得られた成形体の界面付近のSEM 像を Fig.6に示す. 粉 末状態から黒鉛型を用いて焼結した場合に比べて各層の厚み は均一となった。しかし，この手法で作製した場合も，単層 で焼結した場合と比較して，孔が多く密度が高くなかった。 超硬型を用いて高圧を加えても界面付近は圧力の伝播が不十 分な領域となるために密度が上がらなかったものと思われる. さらに, EDXによる成分分析の結果, 本研究の分解能では組 成的に傾斜した拡散層は観察されなかった. 単層で焼結した $\left(\mathrm{Tb}_{0.5} \mathrm{Dy}_{0.5}\right) \mathrm{Fe}_{1.8}$ の伸びが数百 $\mu \mathrm{m}$ であることを考虑すると，効 率よく反りを得るためには試料はできるだけ薄い方が好まし い. しかし，この方法で狫結を行う場合でも得られた試料の 厚みが $1 \mathrm{~mm}$ 以下になると成形体が割れてしまった. 以上のよ うに, 複合化して成形した場合には単層で成形する場合と比 較してより厚い試料でも割れが生じることが多くなった。こ の原因については, 複合化したことによってそれぞれの層の 熱膨張率の相違から大きな応力が発生していることが予想さ れたが, 薄体化することによって発生した応力が材料強度を 上回り，破壊につながったものと思われる．さらに，積層す ることによって焼結体の密度が低くなり, 材料強度を低下さ せたことも破壞しやすくなった一因であると考えられる。

複合型磁歪材料を薄くするために様々な手法を試みた結果， 合金粉末状態で充填する手法では密度を高くすることができ ないことが明らかとなった. 密度が高くならない限り破壊を 防ぐことは困難であると思われる. また，割れていない試料 を機械加工によって薄くする場合も各層の密度が低く, 強度 が低いため, 加工中に容易に割れが生じた.ささらに, 組成傾 斜的拡散層の形成に関しても, 粉末を充填して焼結したから といって必ずしも形成されないことがわかった.これは,PCS 法による昇温や焼結が速く, 拡散層の形成に必要な時間が不

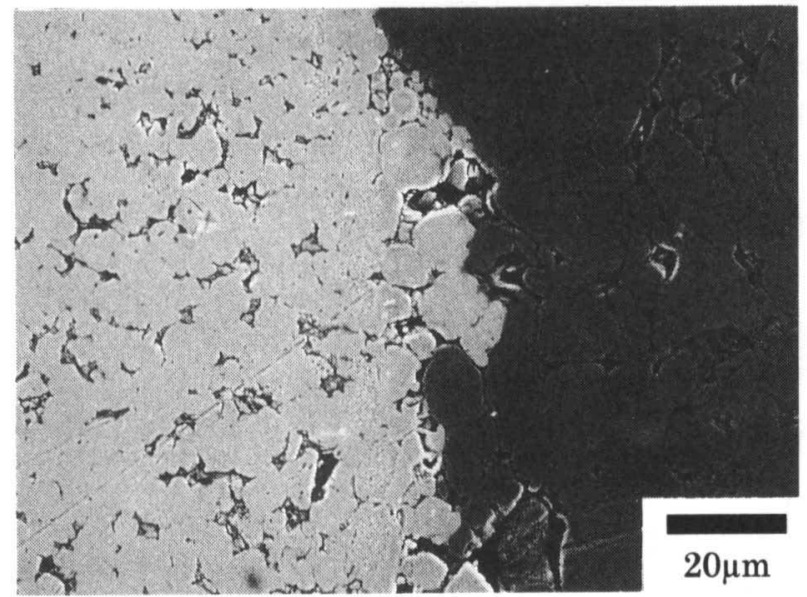

Fig.6 SEM image of $\left(\mathrm{Tb}_{0.5} \mathrm{Dy}_{0.5}\right) \mathrm{Fe}_{1.8} / \mathrm{Fe}-6.5 \mathrm{mass} \% \mathrm{Si}$ interface sintered by using the die made of ultra hard metal at $573 \mathrm{~K}$ and $130 \mathrm{MPa}$ before sintering by using graphite die at 1273 K.
足しているためであると考えられる.つまり，組成傾斜的拡 散層の形成は焼結条件の最適化によって可能であり, 充填初 期の状態にはあまり依存しないといえる。

そこで, 次に, 2層を1回の焼結で同時に固化するのではな く,一方を単層で固化した後，もう一方を固化するという手 法を試みた.単層で成形する場合 $3.1 て ゙$ 述べたように試料の最 小厚みは $0.5 \mathrm{~mm}$ であり, 厚さも均一ではなかった.従って, 試 料をより薄くするためには成形後に機械加工を施す必要があ る. そこで，まずより勒性の高い Fe-6.5mass\%Si合金粉末を， 黒鉛型を用いて41MPa, 1273K, 300秒保持の条件で成形した. 成形後, 試料は平面研削に供し, 厚さを $0.2 \mathrm{~mm}$ とした. 得ら れた $\mathrm{Fe}-6.5 \mathrm{mass} \% \mathrm{Si}$ 合金を黒鉛型に再度装填し，その上から $\left(\mathrm{Tb}_{0.5} \mathrm{Dy}_{0.5}\right) \mathrm{Fe}_{1.8}$ 合金粉末を充填した. 成形は 41MPa, $1273 \mathrm{~K}$, 300 秒保持の条件下で行った.このようにして焼結を 2 回に分 けて行うことによって, 割れのない成形体を得ることが可能 となった. なお, 得られた複合型磁歪材料は TbDy-Fe側を平 面研削することによって最終的に厚さ約 $0.6 \mathrm{~mm}$ の薄い成形体 を得ることができた. 成形体の界面付近の SEM 像を Fig.7に 示す. 粉末を充填する方法に比べて, 孔が少なくなり密度か 高くなっていることがわかる. また, 平面研削を施したこと によって界面形状が平滑となった. EDXによる成分分析の結 果,これまでの結果と同様に組成的傾斜拡散層は確認できな かった.

得られた成形体の反り特性に関しては次報1)で詳細に述べ る.

\section{4 ま と め}

メカニカルアロイング法を利用して合成した，磁歪特性を 示す Tb-Dy-Fe 合金粉末と, 水アトマイス法により作製した， 磁歪特性を示さないFe-6.5mass\%Si合金粉末を積層し, 複合磁 歪材料の作製を試みた結果，以下のことが明らかとなった.

(1) 粉末状態で 2 種類の磁性材料を積層し, 1 度の焼結で固化 した場合，厚さが $1 \mathrm{~mm}$ 以下になると割れが生じた。これ

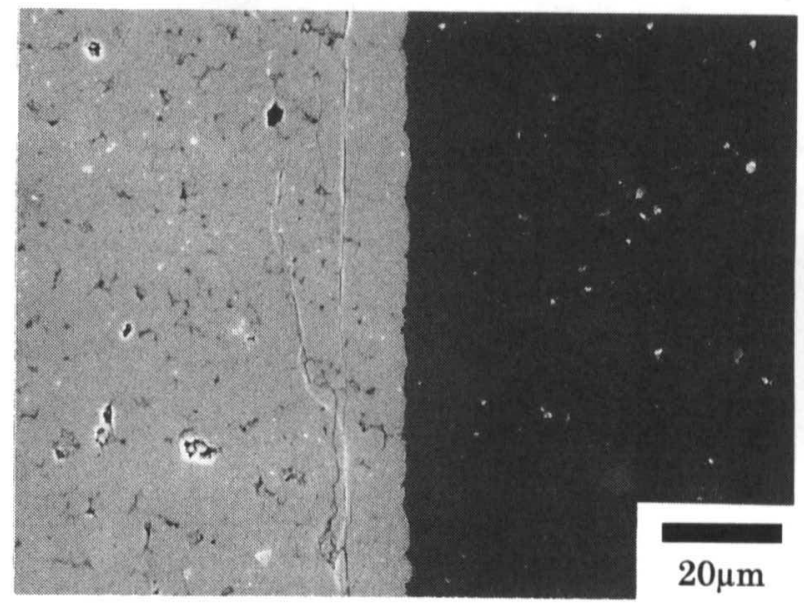

Fig.7 SEM image of sintered $\left(\mathrm{Tb}_{0.5} \mathrm{Dy}_{0.5}\right) \mathrm{Fe}_{1.8} / \mathrm{Fe}-6.5 \mathrm{mass} \% \mathrm{Si}$ interface. Fe-6.5mass\% $\%$ Si alloy was sintered before sintering $\left(\mathrm{Tb}_{0.5} \mathrm{Dy}_{0.5}\right) \mathrm{Fe}_{1.8}$ as the duplex phase magnetic material. 
は，焼結時の試料厚さや圧力の不均一による部分的な密度 不足,および各層の熱膨張率の相違によって発生する熱応 力が原因であると思われる。

(2) 反りが発生する場合,磁歪材料とゼロ磁歪材料の界面では 大きな応力が生じることが予想される.この応力を緩和す る構造として,界面付近での組成傾斜的拡散層の形成を試 みたが,本研究の手法では分析の分解能以上の拡散層は形 成されなかった。

(3) あらかじめゼロ磁歪材料を固化し, 平面研削によって厚さ が一定の薄い試料を作製した後，磁歪材料の粉末を積層し て固化することによって, 厚さが $0.6 \mathrm{~mm}$ 程度の薄い試料 を作製することができた。

\section{謝辞}

最後に，本研究を遂行するにあたり，ゼロ磁䄳材料の合金 粉末をこ提供いただいた大同特殊鋼侏技術開発研究所殿に心 より謝意を表します。

また, 本研究の一部は平成 10 11年度科学研究費補助金に よって実施されたものであり，関係者に改めて謝意を表します。

\section{文献}

1) A.E.Clark and H.S.Belson: "Giant Room-Temperature Magnetostrictions in $\mathrm{TbFe}_{2}$ and DyFe ${ }_{2}$ ", Phys. Rev. B, 5(1972) 3642-3644.

2) M.Wada, H.Uchida and H.Kaneko: "Effect of annealing treatment of the $\mathrm{Tb}_{0.3} \mathrm{Dy}_{0.7} \mathrm{Fe}_{2}$ thin films on the magnetic and magnetostrictive characteristics", J. Alloys and Compounds, 258(1997)
169-173.

3) S.R.Kim and S.H.Lim: "Magnetostriction of rapidly quenched Sm-Fe-B alloys", J. Alloys and Compounds, 258(1997)163-168.

4) D.G.R.Jones, J.P.Fairclough, J.S.Abell and I.R.Harris: "Powder metallurgical processing of $\mathrm{Tb}_{0.27} \mathrm{Dy}_{0.73} \mathrm{Fe}_{2-x}(0<\mathrm{x}<0.5)$ by hydrogen decrepitation", J. Appl. Phys., 69(1991)5774-5776.

5) Wu Mei, T.Umeda, S.Zhou and R.Wang: "Preparation and magnetostriction of Tb-Dy-Fe sintered compacts", J. Magn. Magn. Matter., 174(1997)100-108.

6) F.R. de Boer and K.H.J.Buschow: "Influence of the rare-earth transition-metal interaction on the room temperature magnetostriction", J. Alloys and Compounds, 258(1997)1-6.

7) 本田崇, 林嘉隆, 山口正洋, 荒井賢一: " 磁歪を駆動力とし た薄膜アクテュエーターの試作", 日本応用磁気学会誌, 18 (1994)477-480.

8) N.Tsuya, K.Arai, K.Ohmori and Y.Shiraga: "Magnetostriction measurement by three terminal capacitance method", J. J. Appl. Phys., 13(1974)1080-1810.

9) 杉山明, 小林慶三, 尾崎公洋, 松本章宏, 西尾敏幸, 草加勝 司: “メカニカルアロイングを用いた Tb-Dy-Fe合金の作製 とその固化成形", 粉体および粉末冶金, 46(1999)648-652.

10)杉山明, 小林慶三, 尾崎公洋, 松本章宏, 西尾敏幸: "MASPS プロセスにより作製した Tb-Dy-Fe 合金の磁気特性"， 粉体および粉末治金, 46(1999)1108-1112.

11) 草加勝司, 杉山明, 小林慶三, 尾崎公洋, 松本章宏, 西尾敏 幸：" 複合磁性材料の磁気特性 ", 粉体および粉末治金, 投 稿中. 